\title{
Research
}

\section{Disturbance, Response, and Persistence in Self-Organized Forested Communities: Analysis of Robustness and Resilience in Five Communities in Southern Indiana}

\author{
Forrest D. Fleischman $^{1}$, Kinga Boenning ${ }^{2}$, Gustavo A. Garcia-Lopez ${ }^{1}$, Sarah Mincey ${ }^{3}$, \\ $\underline{\text { Mikaela Schmitt-Harsh }}^{3}, \underline{\text { Katrin Daedlow }}^{4}, \underline{\text { Maria Claudia Lopez }}^{5}, \underline{\text { Xavier Basurto }}^{6}, \underline{\text { Burney Fischer }}^{1}$, and \\ Elinor Ostrom $^{1}$
}

\begin{abstract}
We develop an analytic framework for the analysis of robustness in social-ecological systems (SESs) over time. We argue that social robustness is affected by the disturbances that communities face and the way they respond to them. Using Ostrom's ontological framework for SESs, we classify the major factors influencing the disturbances and responses faced by five Indiana intentional communities over a 15-year time frame. Our empirical results indicate that operational and collective-choice rules, leadership and entrepreneurship, monitoring and sanctioning, economic values, number of users, and norms/social capital are key variables that need to be at the core of future theoretical work on robustness of self-organized systems.
\end{abstract}

Key Words: disturbance; intentional communities; response; robustness; social-ecological systems

\section{INTRODUCTION}

Although many studies have examined humanenvironment interactions, most focus on natural components and a few contain data on social components measured over time. This reflects the difficulty of developing long-term data sets on social-ecological systems (SESs) and the lack of theory to guide such investigations. We develop a theoretical framework to guide the analysis of change over time in SESs, building on the literature on the robustness of SESs (Anderies et al. 2004) and on Ostrom's (2007, 2009, Basurto and Ostrom 2009) ontological framework for analyzing sustainability of SESs to develop a microlevel approach to analyzing how human communities adapt to disturbance. We apply this framework to the analysis of five intentional communities that own forests in southern Indiana and have responded to diverse disturbances.

\section{Theoretical framework}

The core concern in the literature on SESs has been to understand why some systems persist in desirable states over long periods, whereas others do not. The concepts of resilience and robustness both capture the observation that persistence is related to how systems respond to change. Resilience was first used to analyze over-time problems of SESs by ecologists. Contemporary uses in the SES literature draw on the definition offered by Holling: the capacity of a system to maintain structure and function through disturbances, without necessarily returning to a particular reference state (Holling 1973, Harwell et al. 1977, Turner et al. 2003, Folke 2006, Walker and Salt 2006). Although resilience has been useful in ecological studies, it has proved difficult to operationalize in social settings in which humans are able to design rules and anticipate disturbances (Carpenter et al. 2001, Anderies et al. 2004).

\footnotetext{
${ }^{1}$ Workshop in Political Theory and Policy Analysis, School of Public and Environmental Affairs, Indiana University, ${ }^{2}$ Institute of Agricultural Development in Central and Eastern Europe (IAMO), ${ }^{3}$ Center for the Study of Institutions, Population, and Environmental Change, School of Public and Environmental Affairs, Indiana University, ${ }^{4}$ Humboldt Universität zu Berlin, LGF, Division of Resource Economics and Leibniz Institute of Freshwater Ecology and Inland Fisheries (IGB), ${ }^{5}$ Facultad de Estudios Ambientales y Rurales, Universidad Javeriana, ${ }^{6}$ Duke University Marine Laboratory, Nicholas School of the Environment, Duke University
} 
"Robustness" is used in the literature on designed systems in engineering to refer to "the maintenance of desired system performance when subjected to external or internal unpredictable perturbations" (Carlson and Doyle 2002:2539). Anderies et al. (2004) propose that this definition is more applicable to the social aspects of SESs than the related definition of resilience, because human institutions and organizations, like bridges and airplanes, are the result of conscious design. Robust systems have the capacity to continue to meet a performance objective in the face of uncertainty and shocks due to conscious human decisions (Anderies and Janssen 2007). Robustness also captures the problem of trade-offs. Anderies and Janssen provide examples of how systems designed to be robust to certain types of disturbances are frequently less robust to other disturbances. Thus, increasing robustness to one type of disturbance may reduce robustness to another. Anderies and Janssen argue that long-term robustness is a result of modest, short-term cycles of failure and recovery. Modest disturbances or failures allow for learning and evolution to occur and help maintain flexibility. Yet theory does not provide clear guidance for distinguishing which failures will foster long-term robustness and which will lead to system degradation, nor does current theory offer guidance as to what system factors will enhance robustness.

There are challenges in applying a robustness perspective empirically. Because entities that are not robust are unlikely to survive over long periods, it is difficult to avoid sampling bias. In our case, we are aware that many communities analogous to those in our study failed prior to the initiation of our study (Zablocki 1980, Oved 1999). Thus, we are, in effect, sampling on the variable "persistence" that is likely to be closely correlated with the dependent variable. This presents a barrier to making certain kinds of causal claims (King et al. 1994, Brady and Collier 2004). In addition, gathering data on robustness (response to perturbation) is more difficult than gathering data on persistence. A community that persists for a long time - a measure of success frequently used by sociologists studying communities and organizations (Kitts 2000, 2009) - may be robust to perturbations, or it may simply have avoided threatening perturbations due to chance or location in a stable social-political context. Because detailed case analysis is necessary to distinguish the causes of persistence, studies of robustness and resilience tend to be small-N case studies (e.g., Fabricius et al. 2007). These case studies are useful for developing theoretical arguments and understanding complexity but may be insufficient for testing causal claims using techniques drawn from mainstream quantitative social science (King et al. 1994, Ragin 2000, Brady and Collier 2004), particularly situations in which the number of important causal variables may be much larger than the number of cases (Agrawal 2001).

We address these methodological challenges by disaggregating our cases into a larger number of observations that focus on causal processes. King et al. (1994) argue that case studies typically contain many observations. In our study, each community case provides several opportunities to observe disturbances and community responses; thus, our unit of analysis is not communities but disturbances and responses, which are clustered by community. These are the processes that are theorized to form the basis of social robustness. Brady and Collier (2004) argue that observations of the causal process are necessary for understanding causal mechanisms. Even with several observations of key processes in each of the five communities, we do not have enough data to establish correlations between key variables. Our observations of the causal process, however, enable us to develop theory about how robustness develops in SESs. Although all of our communities have persisted for the period of our study, their responses to individual disturbances illustrate the extent to which they are robust to certain classes of disturbances and illustrate that there are multiple causal pathways (Ragin 2000) that lead to the observed outcome of persistence, not all of which reflect equal levels of robustness. In the remainder of this theoretical section, we define the terms and ontological framework that we use to describe the process of disturbance and response that underlies robustness.

\section{Definitions of disturbance, response, and adaptation}

Ecologists define disturbance as "any relatively discrete event in time that disrupts ecosystem, community, or population structure and changes resources, substrate availability, or the physical environment" (White and Pickett 1985:7). Extending this definition to SESs, we define disturbance as a relatively discrete event that disrupts social or ecological communities, resulting in changes to the physical or social environment. It 
is important to recognize that disturbances to the social system may arise from changes in either social or ecological variables and may vary spatially and temporally, existing on continua of magnitude (from minor disagreements to major social conflict or natural disaster) and temporal scale (from the pulse of a flash flood that lasts hours to the press of a drought that lasts years). Long-term disturbances, such as droughts, could be described as continuous; however, we prefer to see them as discrete events occurring over long periods.

Responses can be understood as actions and events that occur in reaction to disturbances. Social responses to disturbances differ from biophysical responses. Biophysical systems respond through selective pressure: aspects of a system that fail cease to exist, and those that work remain. In social systems, humans have, to some extent, the capacity to plan, anticipate, and consciously design their social and physical surroundings. Anticipatory actions are those involving planning or anticipation of a disturbance, that is, acting before a disturbance takes place. Inaction-not responding to a disturbance-is also a response, in the sense that it represents a decision to take no action or an inability to act.

An adaptive response allows the system to "better cope with, manage or adjust to some changing condition, stress, hazards, risk, or opportunity" (Smit and Wandel 2006:282). Along the same lines, maladaptive responses hinder the ability of the system to cope with, manage, or adjust to a change in condition, stress, hazard, risk, or opportunity. In addition, there may be neutral changes or responses that do not alter the ability of the system to cope with, manage, or adjust to a change. The consideration of whether a response is adaptive, maladaptive, or neutral is a normative evaluation of the concept of success. In our analysis, we consider responses that contribute to the persistence of the forest and community in the face of a given disturbance to be adaptive, and we consider those that weakened the community's ability to persist or maintain its forest as maladaptive. It is important to note that inaction, as described above, is not necessarily a maladaptive response. In a world of complex causality, it is entirely possible that a response or anticipatory action may be adaptive in some ways, maladaptive in others, and neutral in others. Thus, the existence of trade-offs-losing one quality or aspect in exchange for another-may be a fundamental aspect of the process of adaptation.

\section{Introduction of the diagnostic ontology}

The analysis of robustness in SESs is hindered by the large number of potential variables of interest (Agrawal 2001). Ostrom's $(2007,2009)$ ontological framework identifies SES variables that explain the nature of disturbances and anticipations/responses within the five communities (Figure 1). This framework is a structured summary of a long tradition of scholarship trying to explain (1) the factors affecting the possibilities of selforganization and collective action and (2) the factors affecting the relative success of management of common-pool resources (Agrawal 2001, National Research Council 2002, Agrawal 2007). A given study does not need to include all variables but rather those that are identified, based on previous research, as most relevant for that particular context. Basurto and Ostrom (2009) first applied this framework to understanding the determinants of collective action and robustness in the context of fisheries. Here we use our data to identify factors that enhanced robustness in forestry-based cases, by tabulating those factors that contributed to enhanced robustness across several cases, as described in Methods. This inductive approach can lead to further theory-building about the determinants of robustness in the social aspects of SESs.

Six sets of variables broadly affect collective action (Table 1, Ostrom 2009): (1) resource system (RS) - such as the clarity of the system's boundaries, its size, its productivity, and the predictability of its dynamics; (2) resource unit characteristics (RU)their mobility, regeneration rate, and economic value; (3) governance system (GS) - the prevalent institutions and norms at different scales (local, national, etc.) and the structure of the network of users; (4) user or group characteristics (U)—such as group size, socioeconomic heterogeneity, history of use of the system, leadership, social capital, and mental models; (5) the social, economic, and political settings (S)-level of economic development, demographic trends, and political stability; and (6) related ecosystems (ECO) including larger-scale water and weather systems. Starred variables in Table 1 are those identified below as having an impact on the process of robustness in at least one disturbance. 
Fig. 1. The first tier of a framework for analyzing an SES. Source: Adapted from Ostrom (2007:15182).

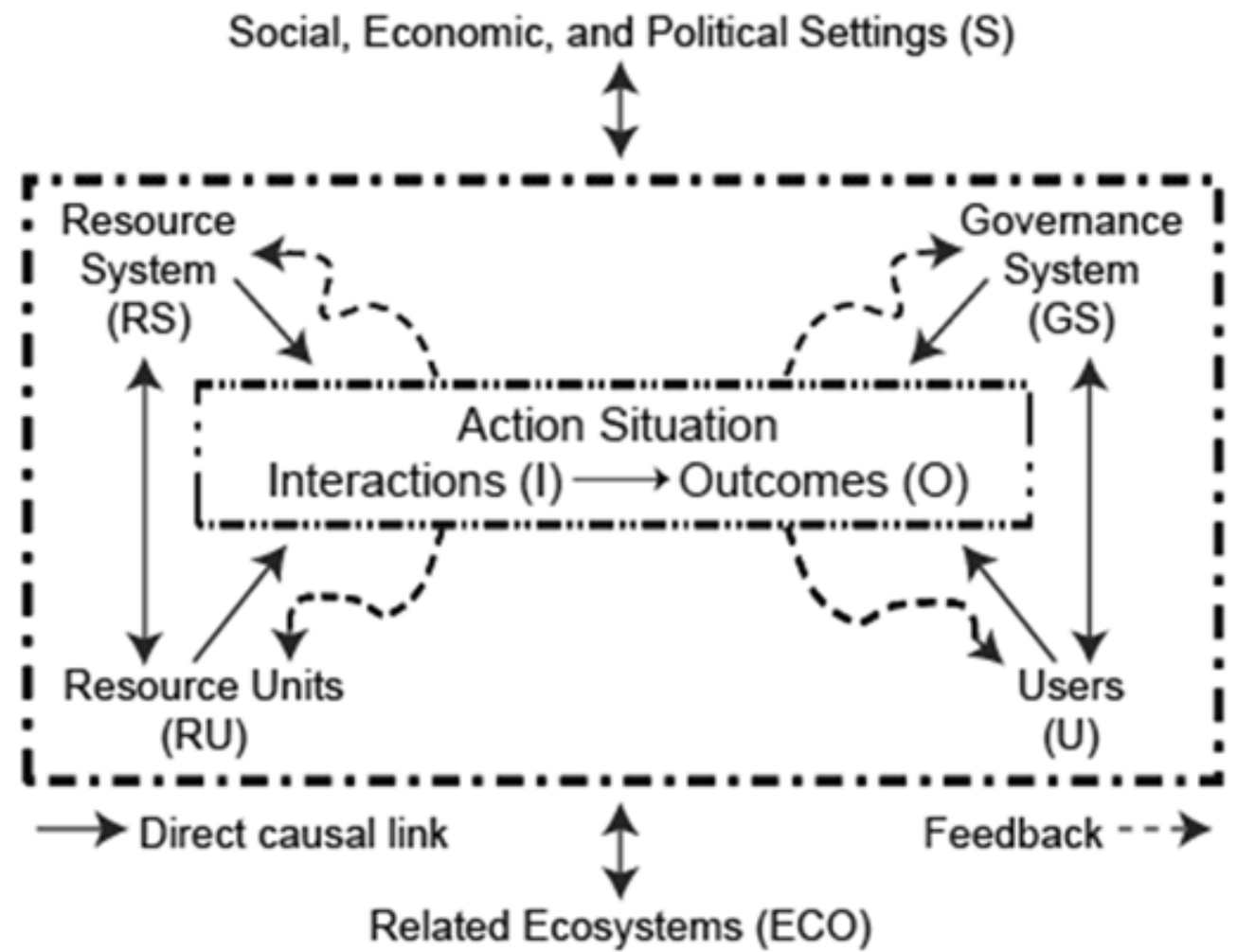

\section{METHODS}

\section{The study system}

Our study examines events at five self-organized intentional communities that own forested land in south-central Indiana. The Fellowship for Intentional Communities (http://www.ic.org/) defines an intentional community as "an inclusive term for ecovillages, cohousing, residential land trusts, communes, student co-ops, urban housing cooperatives, alternative communities, and other projects where people strive together with a common vision." Although similar, self-organized communities have been studied as points of sociological and historical interest (Kanter 1972, 1973, Zablocki 1980, Janzen 1981, Laffan 1997, Brown 2002), the focus has been on social dynamics, not human-environment interaction. All five of our communities were founded during a wave of interest in communal living in the 1960s and 1970s. In a comparative study of intentional communities, Zablocki (1980:2) found that "most of these experiments fail; the few that succeed are usually drastically modified over time." Although there is a sociological tradition of studying the lifespan of communal groups (Kitts 2000, 2009), the focus of these studies has been on statistical analyses of the covariates of communities' lifespan (essentially a "black box" regression approach), whereas our focus is on understanding the processes of adaptation and change, which we argue are the mechanisms that underlie group persistence.

There are three reasons why these intentional communities are good sites for the study of robustness. First, intentional communities in the United States have substantial latitude to organize without interference from external authorities. This enables us to focus on internal dynamics, rather than 
Table 1. Factors that contribute to community responses to disturbances. Adapted from Ostrom (2009:421).

Social, Economic, and Political Settings (S)

${ }^{\dagger}$ S1- Economic development

${ }^{\dagger}$ S2- Demographic trends

${ }^{\dagger}$ S3- Political stability

\section{$\underline{\text { Resource System (RS) }}$}

${ }^{\dagger}$ RS1- Sector (e.g., water, forests, pasture, fish)

RS2- Clarity of system boundaries

'RS3- Size of resource system

RS4- Human-constructed facilities

RS5- Productivity of system

RS6- Equilibrium properties

RS7- Predictability of system dynamics

RS8- Storage characteristics

RS9- Location

\section{Resource Units (RU)}

RU1- Resource unit mobility

RU2- Growth or replacement rate

'RU3- Interaction among resource units

RU4- Economic value

RU5- Number of units

RU6- Distinctive markings

RU7- Spatial and temporal distribution

I1- Harvesting levels of diverse users

I2- Information sharing among users

I3- Deliberation processes

I4- Conflicts among users

I5- Investment activities

I6- Lobbying activities

I7- Self-organizing activities

I8- Networking activities
S4- Government settlement policies

S5- Market incentives

S6- Media organization

\section{Governance System (GS)}

GS1- Government organizations

GS2- Non-government organizations

GS3- Network structure

GS4- Property-rights systems

GS5- Operational rules

GS6- Collective-choice rules

GS7- Constitutional rules

${ }^{\dagger}$ GS8- Monitoring and sanctioning processes

\section{Users (U)}

U1- Number of users

U2- Socioeconomic attributes of users

UU3- History of use

UU- Location

U5- Leadership/entrepreneurship

U6- Norms/social capital

U7- Knowledge of SES/mental models

U8- Dependence on resource

U9- Technology used

$\underline{\text { Interactions }(\mathrm{I}) \rightarrow \text { Outcomes }(\mathrm{O})}$

O1- Social performance measures

(e.g., efficiency, equity, accountability)

$\mathrm{O} 2$ - Ecological performance measures

(e.g., overharvested, resilience, diversity)

O3- Externalities to other SESs

$\underline{\text { Related Ecosystems (ECO) }}$

ECO1- Climate patterns

ECO2- Pollution patterns

ECO3- Flows into and out of focal SES

$\dagger$ Variables that are identified with explanatory power in our case study analysis. 
on the complex regional and national politics that determine land use in many contexts. This does not mean that our analysis is relevant only for communities that lack external disturbances. Rather, the analysis shows that careful over-time case study comparison guided by a clear theoretical framework can help illuminate how communities persist over time while responding to different disturbances. The real value is in the generalizability of our approach, which can deal effectively with complexity, and not of the generalizability of particular community characteristics. Second, each of these communities has experienced several disturbances, allowing multiple observations of response processes. Finally, each community has been studied by researchers from the International Forestry Resources and Institutions (IFRI) research program for 15 years, providing a data set with unusual social-ecological and over-time coverage.

\section{IFRI methods}

The IFRI research program was started in the early 1990 s by scholars interested in understanding institutions that facilitated collective action in forest management (Ostrom and Wertime 2000, Wollenberg et al. 2007, Poteete and Ostrom 2008). IFRI aimed to address two shortcomings in the literature. First, case study findings could not easily be generalized. Second, scholars from diverse disciplines used inconsistent terminology and data measurement techniques, hindering a synthesis that could contribute to generalized theory. IFRI developed a consistent methodology, with a set of common research instruments, to measure both social and ecological (forest) conditions across many sites and over time to develop a large-N database. To date, the IFRI program has collected data at more than 250 sites in 15 countries, including the 5 sites analyzed in this study that have been used for IFRI training seminars at Indiana University.

IFRI research combines standard techniques for forest mensuration with tools drawn from Participatory Rural Appraisal (Chambers 1994), including participatory mapping, participant observation, focus groups, and semistructured interviews. All information is entered onto standard IFRI coding forms (Wertime et al. 2007) and then entered into a relational database. Copies of IFRI coding forms and information on access to the IFRI database are available from the IFRI center at the University of Michigan (http://www.sitemaker.umich. edu/ifri/home). Each of the sites in this study has been visited three times, at approximately 5-year intervals, between 1994 and 2008. Site visits were conducted as part of annual IFRI training seminars and involved teams of 6-10 graduate students, visiting IFRI scholars, and resident faculty. As the sites are all within a 30-minute drive of the IUBloomington campus, each visit included numerous trips to the community over a 2-month period to conduct forest mensuration, map key characteristics of the forest, and conduct extensive interviews with and observations of community members. Our analysis is based on reports written for the communities after each site visit, information stored in the IFRI database, and our own experiences visiting the five communities. The names of the communities have been changed to protect their identities; however, the names are consistent with previous publications (Gibson and Koontz 1998, Poteete and Welch 2004).

\section{The five communities}

Maple was founded in 1976 on 300 acres $(66 \%$ forested) by a group of young people. Over time, the community has fluctuated between 10 and 40 members at its peak. It now has 23 members who are rather homogeneous in terms of values and socioeconomics. Decisions used to be made by a consensus but are now made by majority rule (Table 2).

Oak was founded in the late 1960s when a wealthy couple purchased over 1000 acres and sought likeminded individuals to form a community. Emphasis was placed on developing a spiritual relationship with the earth, but the recruits were relatively heterogeneous. Membership stabilized to approximately 40 individuals in the mid-1970s. Community members formed a "church" to serve as a legal entity to hold the property after the founders sold half the property and left the community. Decisions are made by majority rule, although consensus is preferred. Due to multiple conflicts that have landed in court, membership declined to 10 people in the last 15 years, leading to greater homogeneity (Table 2).

The Box Elder community began in 1983. Initially, the stable, homogeneous, 20-member group held fairs and festivals to raise funds and celebrate a spiritual connection to nature at local state parks. In 1987, they purchased 109 acres (83\% forested). 
Table 2. Characteristics of five forest communities in southern Indiana.

\begin{tabular}{|c|c|c|c|c|c|}
\hline & Maple & Oak & Box Elder & Twin Oaks & Tulip Poplar \\
\hline Origin & 1976 & $\begin{array}{l}\text { Late } 1960 \text { s to early } \\
1970 \text { s }\end{array}$ & 1983 & 1971 & 1969 \\
\hline Area (acre/ha) & $304 / 123$ & $450 / 182$ & $109 / 44$ & $140 / 57$ & $1100 / 445$ \\
\hline Forested (acre/ha) & $\begin{array}{l}200 / 81 \\
(66 \% \text { of area })\end{array}$ & $\begin{array}{l}110 / 45 \\
(25 \% \text { of area })\end{array}$ & $\begin{array}{l}90 / 36 \\
(83 \% \text { of area })\end{array}$ & $\begin{array}{l}120 / 49 \\
(86 \% \text { of area })\end{array}$ & $\begin{array}{l}590 / 239 \\
(54 \% \text { of area })\end{array}$ \\
\hline Timber harvest & No & Yes & No & No & Yes \\
\hline Founding members & About 10 & 2 & About 20 & 2 & 2 \\
\hline Group size change & $\begin{array}{l}\text { Slowly increasing } \\
\text { up to } 40 \text { people; } \\
\text { decline after fire in } \\
1980 ; 23 \text { members } \\
\text { today }\end{array}$ & $\begin{array}{l}\text { First increasing up } \\
\text { to } 40 \text { people; } \\
\text { decrease after } \\
\text { conflicts; about } 10 \\
\text { people today }\end{array}$ & $\begin{array}{l}\text { Members: stable } \\
\text { Festival visitors: } \\
\text { increasing } \\
\text { (hundreds) }\end{array}$ & $\begin{array}{l}\text { Two friends were } \\
\text { included very } \\
\text { early, now only } \\
\text { one member left }\end{array}$ & $\begin{array}{l}\text { Selling of } 1 \text {-acre } \\
\text { lots to private } \\
\text { individuals; } 527 \\
\text { permanent adult } \\
\text { residents today }\end{array}$ \\
\hline $\begin{array}{l}\text { Group } \\
\text { heterogeneity }\end{array}$ & Low & $\begin{array}{l}\text { First high, today } \\
\text { low }\end{array}$ & Low & Low & High \\
\hline $\begin{array}{l}\text { Motivation to start } \\
\text { community }\end{array}$ & $\begin{array}{l}\text { Community life; } \\
\text { back-to-the-land }\end{array}$ & $\begin{array}{l}\text { Community life; } \\
\text { securing gathering } \\
\text { space }\end{array}$ & $\begin{array}{l}\text { Spiritual refuge; } \\
\text { securing gathering } \\
\text { space }\end{array}$ & Privacy in nature & $\begin{array}{l}\text { Privacy; residential } \\
\text { development; } \\
\text { recreation }\end{array}$ \\
\hline Governance & $\begin{array}{l}\text { All members and } \\
\text { council }\end{array}$ & All members & Elder council & All members & $\begin{array}{l}\text { Board of nine } \\
\text { directors }\end{array}$ \\
\hline Decision making & $\begin{array}{l}\text { First consensus, } \\
\text { later majority rule }\end{array}$ & Majority rule & $\begin{array}{l}\text { First consensus, } \\
\text { later majority rule }\end{array}$ & Consensus rule & Majority rule \\
\hline $\begin{array}{l}\text { Internal social } \\
\text { disturbances }\end{array}$ & $\begin{array}{l}\text { Tree cutting; } \\
\text { change of } \\
\text { generations }\end{array}$ & $\begin{array}{l}\text { Tree cutting; } \\
\text { leadership/ } \\
\text { membership }\end{array}$ & $\begin{array}{l}\text { Tree cutting; } \\
\text { leadership }\end{array}$ & $\begin{array}{l}\text { Moving away and } \\
\text { death of members }\end{array}$ & $\begin{array}{l}\text { Tree cutting; } \\
\text { change of } \\
\text { generations }\end{array}$ \\
\hline $\begin{array}{l}\text { External social } \\
\text { disturbances }\end{array}$ & $\begin{array}{l}\text { Poaching; } \\
\text { hostility from } \\
\text { neighbors }\end{array}$ & $\begin{array}{l}\text { Poaching; } \\
\text { trespassing; } \\
\text { conflict with } \\
\text { neighbors }\end{array}$ & $\begin{array}{l}\text { Trespassing; } \\
\text { hostility from } \\
\text { neighbors }\end{array}$ & $\begin{array}{l}\text { Trespassing; } \\
\text { poaching }\end{array}$ & $\begin{array}{l}\text { Trespassing; } \\
\text { poaching }\end{array}$ \\
\hline $\begin{array}{l}\text { Natural } \\
\text { disturbances }\end{array}$ & Fire in 1980 & None & None & None & $\begin{array}{l}\text { Lake-level } \\
\text { differences; } \\
\text { flood in 2008; } \\
\text { erosion at lakes/in } \\
\text { forests }\end{array}$ \\
\hline
\end{tabular}


Governance of the community rests with an elder council; decisions were first made by consensus, but later by majority rule. In recent years, internal conflicts led to a substantial community restructuring, as an important leader was expelled and the community incorporated as a legal nonprofit (Table 2).

The community of Twin Oaks began in 1948 when a group of investors purchased 120 acres of land as a tax sale. In 1971, one investor obtained full ownership for his son who, along with a college fraternity brother, purchased 120 acres as coowners, and later purchased an additional 20 acres to facilitate access from the public road. To finance improvements, the two young men sold two 20 -acre parcels delineated from the original 120 acres to two additional friends in 1976. Eighty-six percent of the land is forested, has not been harvested, and falls partly under joint and private ownership. Governance was shared equally among members, and decisions were made by consensus. The number of community members remained constant for 30 years; however, immediately prior to our last site visit, in 2008, one member died and two moved away. Although this site cannot be considered a community today, we analyzed data from the 10 years before this change (Table 2).

Tulip Poplar was founded in 1969 by two real estate developers who initially intended to create a retirement and vacation community on 1100 acres. The land is $54 \%$ forested, with two manmade, communally owned lakes. Through the selling of small private lots, today there are 527 permanent adult residents. An elected board of nine directors governs this relatively heterogeneous community by majority rule. Forest ownership is a mix of private and communal tenure, and unlike the other four communities, there have been significant timber harvests on both private and public forests (Table 2).

\section{Shared settings}

All of the five communities share a supportive context for self-organization. Property rights and the rule of law are strong. In contrast to community forests in many developing countries (White and Martin 2002, Larson and Ribot 2007, Agrawal et al. 2008, Sunderlin et al. 2008), none of these five communities has faced attempts by governments or other powerful actors to take their land through legal or extralegal means. This is captured in the framework variable S3, political stability. In addition, the members of the communities are participants in a prosperous regional economy that enables them to earn a living without exploiting the natural resources on their land. This is captured in framework variable S1, economic development. As a result, the primary land uses are nonconsumptive. This does not mean the land is not important; community members clearly value their forests very deeply, and in some cases the forest has a spiritual value, analogous to sacred groves found in China, Ghana, India, Mexico, Nepal, Thailand, Uganda, and Zimbabwe (Ostrom 2005:235). No variable in the existing framework adequately captures these spiritual values. However, framework variable RU4, economic value, could be modified to capture these spiritual values, which are difficult to integrate into a political economic framework.

\section{Method of analysis}

As discussed above, there is little existing theory to guide our search for factors that enable communities like those in our study to respond adaptively to disturbances. Our goal was to identify important factors in a way that would make our findings directly comparable to similar analysis from other systems. In order to do this, we relied on Ostrom's (2007, 2009) diagnostic framework. This was not straightforward, as the data were collected originally with different variables in mind, as described in the IFRI protocol (Wertime et al. 2007). Thus, we relied on an extensive process of crosschecking between past research reports and members of research teams to ensure consistent application of the framework to reliable data. The first step in this process was for teams of two researchers to review all of the past information on a single community and identify past disturbances and responses. These teams then presented the information to the larger group, which included individuals who had been part of past visits to all of the sites, who added their extensive individual knowledge of the cases. Any inconsistencies were checked against past field notes and reports.

Not surprisingly, given the many similarities across the communities, they have experienced some similar types of disturbances. After we identified these similar types, we returned to our smaller teams and coded the identified disturbances into types, identified the most important proximate factors 
contributing to the disturbance, and classified them according to the second-tier variables in Ostrom's framework (Table 3). We analyzed responses in the same way. Again, these were presented to the larger research team, leading to extensive discussions to ensure that framework variables were coded consistently across cases. We then tabulated our findings in order to identify those factors that were important across many disturbances of similar type, and further those variables that were important across all types of disturbances.

In following this approach, we strike a middle ground between individual or paired case studies, which offer maximal opportunity for rich description but offer limited opportunities to generalize, and large-N statistical analyses, which have broader external validity but struggle to operationalize complex concepts. Analyses with a small to medium number of cases are relatively rare but offer promise in terms of their ability to aid the development of theories with broad applicability (Ragin 2000). Thus, our approach to analysis is itself a finding, in the sense that it could be applied by other researchers who possess detailed data on a number of cases too large to be described in a detailed case study, but too small to model using conventional statistical approaches.

There are several important limitations to our methods. First, as mentioned in the introduction, it can be difficult to distinguish random effects from the avoidance of disturbance due to anticipatory action or good luck. Thus, it is possible that some of our variables are associated with random effects and not with robustness. Second, our tabular analysis of important variables across cases might compile factors that enhance robustness to any disturbance, potentially obscuring the role of specific variables in robustness to particular kinds of disturbances. Thus, variables that were very important for a certain kind of disturbance that occurs rarely in our data set may be undervalued. Third, historical data collected using the IFRI methodology were not explicitly designed for analysis using Ostrom's framework, and thus the research team had to evaluate how the existing data could be coded into new variables. Finally, our strategy of focusing on a limited population of cases (intentional communities in southern Indiana), although conducive to analysis of internal dynamics, limits the external validity of our study in terms of types of communities, though not in terms of types of disturbances and responses. Many of the disturbances documented in forest-owning communities in other parts of the world (e.g., forest fires, actions by predatory government institutions, and timber theft) are not present here.

\section{RESULTS}

\section{Common disturbances}

The five communities experienced five types of disturbances (Table 3). Three types of disturbances originate inside of the community: controversy over tree cutting, controversy over leadership, and membership transitions. Two types of disturbances are external to the communities: conflicts with neighbors and natural disasters. Although natural disasters and tree cutting have ecological components, we focus on the social components of these disturbances, because, as discussed in the introduction, these have not been well studied in previous work on SESs. Disturbances range in time scale from discrete events, such as floods, to long processes, such as membership transitions. They also range in magnitude from very mild, such as the cutting of a small number of trees that violates community norms, to very severe, such as a fire that destroyed a young community's only building and nearly led to that community's dissolution. Although some disturbances caused clear and immediate threats to a community's survival, most did not. Successful response to small disturbances may enhance a community's robustness to future, larger disturbances (Anderies and Janssen 2007).

When communities have faced similar disturbances, their responses are indicative of their differing abilities to engage in adaptive behavior. Four of five communities have faced serious disturbances related to the cutting of trees that went against community rules and norms. Two communities have faced serious disturbances related to leadership, whereas the other three appear to have prevented such disturbances (although it is difficult to tell whether this is due to anticipatory behavior or good luck). Although property rights in the United States are strong, all five communities have faced disturbances related to trespassing, illegal harvesting of nontimber forest products, and relations with neighbors. All five communities have faced disturbances related to changing membership, particularly as it relates to generational change. Finally, two communities have faced serious natural disasters. 
Table 3. Factors leading to disturbances and responses in the five communities.

\begin{tabular}{|c|c|c|c|c|c|}
\hline Community & Event & $\begin{array}{l}\text { Factors leading to } \\
\text { disturbance (or lack } \\
\text { of, if no disturbance) }\end{array}$ & $\begin{array}{l}\text { Factors leading to } \\
\text { response }\end{array}$ & Nature of response & $\begin{array}{l}\text { Adaptiveness of } \\
\text { response }\end{array}$ \\
\hline
\end{tabular}

Disturbance: Tree cutting

\begin{tabular}{|c|c|c|c|c|c|}
\hline Maple & $\begin{array}{l}\text { Tree cutting on } \\
\text { private home site }\end{array}$ & GS8 & U6 & $\begin{array}{l}\text { Did not enforce rule } \\
\text { in favor of } \\
\text { maintaining } \\
\text { community norm }\end{array}$ & Neutral \\
\hline Oak & $\begin{array}{l}\text { Tree cutting on } \\
\text { privatized lots }\end{array}$ & GS5, U1, U6 & GS6, U6 & No response & Maladaptive \\
\hline Box Elder & $\begin{array}{l}\text { Tree cutting on } \\
\text { common land }\end{array}$ & GS5, U1, U6 & U6 & Creating formal rules & Adaptive \\
\hline Twin Oaks & None & U1, U6 & - & - & $\begin{array}{l}\text { Anticipatory/ } \\
\text { adaptive }\end{array}$ \\
\hline Tulip Poplar & $\begin{array}{l}\text { Tree cutting on } \\
\text { privatized lots }\end{array}$ & GS5, U7, RU3 & GS6, U6 & Creating formal rules & Adaptive \\
\hline \multicolumn{6}{|c|}{ Disturbance: Leadership } \\
\hline Maple & None & GS6, U5, U6 & - & - & $\begin{array}{l}\text { Anticipatory/ } \\
\text { adaptive }\end{array}$ \\
\hline Oak & $\begin{array}{l}\text { Two conflictive } \\
\text { factions within } \\
\text { community over } \\
\text { leadership right }\end{array}$ & GS6, U5, U7 & GS6 & $\begin{array}{l}\text { External court } \\
\text { decision, but conflict } \\
\text { reemerged }\end{array}$ & Maladaptive \\
\hline Box Elder & $\begin{array}{l}\text { One leader misused } \\
\text { community funds and } \\
\text { was investigated for } \\
\text { drug issues }\end{array}$ & GS5, GS6, GS8, U5 & GS6, GS7 & $\begin{array}{l}\text { Leader was removed } \\
\text { and bylaw changes } \\
\text { enacted }\end{array}$ & Adaptive \\
\hline Twin Oaks & None & U1, U5, U6, U7 & - & - & $\begin{array}{l}\text { Anticipatory } / \\
\text { adaptive }\end{array}$ \\
\hline Tulip Poplar & None & GS5, GS6, GS7, U5 & - & - & $\begin{array}{l}\text { Anticipatory/ } \\
\text { adaptive }\end{array}$ \\
\hline \multicolumn{6}{|c|}{ Disturbance: Boundaries and neighbors } \\
\hline Maple & $\begin{array}{l}\text { Poaching of ginseng } \\
\text { and morels; hostility } \\
\text { from neighbors }\end{array}$ & GS8, U1, RS3 & GS3 & $\begin{array}{l}\text { Cooperation with } \\
\text { neighbors; monitoring } \\
\text { by members }\end{array}$ & Maladaptive \\
\hline Oak & $\begin{array}{l}\text { Trespassing to use } \\
\text { lake and forest; } \\
\text { poaching of ginseng; } \\
\text { conflict with neighbor } \\
\text { over hayfield }\end{array}$ & GS8 & U6 & $\begin{array}{l}\text { Monitoring by } \\
\text { members }\end{array}$ & Maladaptive \\
\hline Box Elder & $\begin{array}{l}\text { Trespassing for } \\
\text { hunting and bathing } \\
\text { in the river; ATVs; } \\
\text { hostility from } \\
\text { neighbors }\end{array}$ & GS8 & GS3, GS5, U6 & $\begin{array}{l}\text { Changed rules; } \\
\text { strong shared norms; } \\
\text { cooperation with } \\
\text { neighbors; } \\
\text { fencing; } \\
\text { monitoring by } \\
\text { members }\end{array}$ & Adaptive \\
\hline
\end{tabular}




\begin{tabular}{|c|c|c|c|c|c|}
\hline Twin Oaks & $\begin{array}{l}\text { Trespassing for } \\
\text { hunting; ATVs }\end{array}$ & GS8, U1, RS3 & GS8 & $\begin{array}{l}\text { Fencing; } \\
\text { monitoring by } \\
\text { members }\end{array}$ & Maladaptive \\
\hline Tulip Poplar & $\begin{array}{l}\text { Trespassing to use } \\
\text { lake and forest }\end{array}$ & GS8 & GS5, GS6 & $\begin{array}{l}\text { Monitoring by } \\
\text { security committee } \\
\text { and volunteers }\end{array}$ & Adaptive \\
\hline \multicolumn{6}{|c|}{ Disturbance: Membership transition } \\
\hline Maple & $\begin{array}{l}\text { Membership decline } \\
\text { following fire; } \\
\text { tensions over } \\
\text { incorporating children } \\
\text { of members }\end{array}$ & GS4, GS7 & U6 & $\begin{array}{l}\text { Changed shared } \\
\text { norms to adopt a new } \\
\text { vision of the } \\
\text { community }\end{array}$ & Adaptive \\
\hline Oak & $\begin{array}{l}\text { Departure of members } \\
\text { following group } \\
\text { conflicts }\end{array}$ & GS7, U5, U6 & GS6 & $\begin{array}{l}\text { Ceased regular } \\
\text { meetings }\end{array}$ & Maladaptive \\
\hline Box Elder & $\begin{array}{l}\text { Large festivals that } \\
\text { bring in outsiders } \\
\text { unaware of rules }\end{array}$ & I5 & GS5, GS8 & $\begin{array}{l}\text { Created formal rules } \\
\text { to regulate outsiders }\end{array}$ & Adaptive \\
\hline Twin Oaks & $\begin{array}{l}\text { Death of a member } \\
\text { leading to small group } \\
\text { size }\end{array}$ & $\mathrm{U} 1$ & $\mathrm{U} 1, \mathrm{U} 7$ & No response & Maladaptive \\
\hline Tulip Poplar & $\begin{array}{l}\text { Changed community } \\
\text { composition (from } \\
\text { mostly retirement to } \\
\text { also young people, } \\
\text { families) }\end{array}$ & S2 & GS6, GS7 & $\begin{array}{l}\text { Created formal rules } \\
\text { to share decision } \\
\text { making }\end{array}$ & Adaptive \\
\hline \multicolumn{6}{|c|}{ Disturbance: Natural disasters and "Acts of God" } \\
\hline Maple & House fire & Stochastic event & $\mathrm{U} 2$, U5 & $\begin{array}{l}\text { Large part of } \\
\text { community members } \\
\text { left; } \\
\text { remaining members } \\
\text { went on to different } \\
\text { shared norms }\end{array}$ & Adaptive \\
\hline Oak & None & None & - & - & - \\
\hline Box Elder & None & None & - & - & - \\
\hline Twin Oaks & None & None & - & - & - \\
\hline Tulip Poplar & Flood & Stochastic event, U4 & GS3, U5 & $\begin{array}{l}\text { Application for state } \\
\text { and federal disaster } \\
\text { assistance; } \\
\text { potential restructure } \\
\text { of governance } \\
\text { arrangements }\end{array}$ & Unclear \\
\hline
\end{tabular}

\section{Cutting of trees that violates rules or norms}

The forests owned by all five communities are managed primarily for nonconsumptive uses, with tree cutting either prohibited or severely restricted. Four of the five communities have experienced tree cutting that violated nonconsumptive norms (Table
3). These disturbances have ranged in size from the cutting of a small number of trees to build a house addition at Maple to clear-cutting several acres at Oak.

In three of the four cases, a major contributing factor leading to disturbance was a lack of rules (GS5) to 
back up existing norms against tree cutting. As we define it, a norm is an institutional prescription for behavior, whereas a rule is an institutional prescription for behavior accompanied by an "or else" statement, which may be formally recorded, as in a law, or may be informal, as in social sanctioning (Crawford and Ostrom 1995, Ostrom 2005, Basurto et al. 2009). In Box Elder, where the forest is considered sacred and a strong norm existed against tree cutting, trees were cut by a group of volunteers who claimed to be unaware of this norm. This points to the importance of shared understanding of norms (U6) among all types of users, even nonmembers or volunteers (U1). At Tulip Poplar, where tree cutting was unregulated on private plots, the community first became aware of potential externalities from tree cutting when a private landowner cleared a steep slope adjoining a lake, leading to severe erosion. Prior to this, the community's knowledge of its ecology (U7) did not include the possibility that behavior on private lots could negatively impact the lake (a case of resource system interaction between forested land and the lake [RU3]), and there had been no rules or norms regarding tree cutting (GS5). Similarly, at Oak, there were no rules regarding tree cutting (GS5), although there was a norm against tree cutting. When the community privatized land in order to increase membership (U1), new landowners did not share norms about forest use (U6), and subsequent tree cutting occurred. The cases of Oak and Box Elder indicate that there may be a trade-off between inviting outsiders in to increase group size (U1) and maintaining shared norms (U6). The flip side of this trade-off can be seen at Twin Oaks, where there have been no tree-cutting disturbances due to a combination of a very small community with strongly shared norms (U1 and U6), but where small size threatens the long-term viability of the community. Maple had anticipated the problem of tree cutting on privatized home sites and created formal rules restricting tree cutting on private plots; however, a landowner building an addition onto his house intentionally violated this formal rule, suggesting that lack of monitoring and sanctioning (GS8) can result in such disturbance as well.

Community responses to the disturbance of tree cutting can be divided into two types. First, two communities (Twin Oaks and Maple) acted in ways that anticipated and prevented future disturbances. At Twin Oaks, the decision to stay small unintentionally helped the community, whereas at Maple, this was the result of a conscious effort to control land uses on semi-privatized home sites
(Gibson and Koontz 1998). Unfortunately, as the experience at Maple demonstrates, the existence of a formal rule does not guarantee adequate enforcement. When rules regulating land use on home sites were violated, a broader norm of maintaining community harmony (U6) appears to have prevented the community from seeking punitive actions against the perpetrators (i.e., enforcing the "or else" clause of the rule). There is some controversy in the literature about whether communities that violate formal rules in order to maintain social cohesion are engaging in maladaptive behavior (Cleaver 2000, FernandezGimenez et al. 2008). In this particular case, Maple's decision appeared to be neutral. Choosing not to enforce a formal rule, which the community had created through a consensus process to reinforce a norm, undermined the community's faith in its ability to make and enforce collective decisions, but it also helped maintain group cohesion. More importantly, the number of trees lost here relative to the size of Maple's forest was quite small, and the conflict alone may have been sufficient to deter potential future rule breakers.

Two communities responded adaptively after disturbance by creating formal rules to prevent unwanted tree cutting in the future. At Box Elder, the new formal rule simply reinforced an existing norm, making it more visible to less involved members of the community. At Tulip Poplar, the formal rule (and accompanying enforcement mechanism) built on an existing institution at the collective-choice level (GS6), a committee that already governed land use on commonly owned lands, to regulate tree cutting on private land.

Finally, Oak responded to the first instance of this disturbance, in 1993, by taking to court the landowner who clear-cut his lot, taking advantage of the nested nature of community governance within a broader collective-choice legal structure (GS6). The court case was unsuccessful because the community did not have the right to challenge land use on private lands. The judge suggested that for the future, the community change its rules to put an easement on future privatized land that would prevent tree cutting. The community did not follow his advice, and the disturbance recurred in 2003. The community did not respond to the second occurrence. Gibson and Koontz (1998) argued that tree cutting at Oak was the result of a failure to develop rules that enforced existing values and norms. 
Why did Oak fail when the other four communities were able to either anticipate or adaptively respond to tree-cutting disturbances? The answer may lie in the different formation processes of the communities. Unlike the other four communities, the residents of Oak received their land as a gift from a wealthy landowner and recruited new members by openly inviting people at a city park to join them. This was a trade-off. Ease of acquiring land led to reduced transaction costs in forming the community, but the experiences of other communities suggest that collective efforts to organize common land help build shared values and norms. As a result, in Oak, there were neither shared experiences, shared values, nor preexisting rules (U6) to tie community members together. Moreover, whereas both Oak and Maple allowed privatization of homes as a way to allow members to transition to a more typical American lifestyle and, at Oak, as an attempt to attract members, Maple carefully developed rules to ensure that community norms would be followed on semi-private home sites, whereas Oak has passed up repeated opportunities to develop rules that would enforce community norms on privatized sites.

\section{Leadership}

Two of the five communities have suffered disturbances related to leadership: Oak and Box Elder (Table 3). Failures to develop or adhere to collective-choice rules (GS6) contributed to Oak's leadership disturbance. Although Oak's original bylaws established a leadership council of seven members (U5), loss of membership led to informally established leadership via a president, secretary, and treasurer (GS6). Around the same time, in the early 1990s, two internal factions developed, each with a different leader (U5), representing different mental models (U7) regarding land use and membership rules. Conflict between the two groups' visions of the community centered on whether members could hold private property rights and whether those property rights implied the right to cut down trees, in violation of community rules. When the community was unable to resolve the conflict internally, the issue was taken to court. Although the court resolved the conflict, the community incurred considerable financial losses as a result of legal fees and also saw a further decline in membership. Moreover, the conflict reemerged years later, and to the extent that it has been resolved, has been resolved by the departure of key voices in the conflict. In this case, reliance on external institutions rather than strengthening communal collective-choice processes and its leadership contributed to the continued presence of internal divisions.

In contrast, Box Elder was able to resolve its leadership crisis without such negative consequences. The community's charismatic founder and spiritual leader became increasingly conflictive, misused communal funds, and became the target of a law enforcement investigation. The personality of this leader (U5) was a factor contributing to this disturbance, as was the absence of operational and collective-choice rules to adequately monitor and make the individual accountable for his actions (GS5, GS6, GS8). In response, the elected Council of Elders removed him from power and enacted changes to their bylaws. The community reorganized as a federally overseen $501 \mathrm{C}(3)$ nonprofit, requiring a well-defined governance structure. The community also changed its collective-choice rules from consensus to majority rule and began holding monthly meetings and weekly "office hours," allowing greater flexibility and transparency as well as increasing opportunities for member involvement. The community was able to take such action because of collective-choice rules and constitutional rules that allowed for change and adaptation (GS6, GS7).

The three communities that have not faced leadership disturbances-Twin Oaks, Maple, and Tulip Poplar-have avoided this type of disturbance through governance systems that distribute power between members (U5) and encourage transparency. Maple and Tulip Poplar have clear collective-choice rules that foster constructive decision making and long-term flexibility in community structure (GS6); and, in Tulip Poplar, these are reinforced through both operational and constitutional rules (GS5, GS7). Members of Twin Oaks and Maple have strong shared norms and values (U6). In Twin Oaks, this was enhanced by similar mental models (U7) among the members of the very small group (U1). Although these arrangements have avoided leadership conflicts, they also create trade-offs. Twin Oaks's small size, which has allowed transparency and shared norms to persist, also threatens its longevity. Tulip Poplar's large size and reliance on democratic processes has avoided leadership dilemmas, but has produced complaints of slow decision making and other problems typical of larger bureaucracies. 


\section{Boundaries and neighbors}

Although the United States is known for having some of the world's strongest institutions for landbased private property rights (GS4), all five communities have faced disturbances related to maintaining boundaries (RS2) and relations with neighbors. Trespassing to hunt, fish, drive allterrain vehicles (ATVs), or poach morel mushrooms (Morchella spp.) and wild ginseng (Panax quinquefolius) occurs at all five sites. All communities experienced difficulty in monitoring and sanctioning against trespassing (GS8). For communities like Maple and Twin Oaks, this difficulty was largely attributable to a disproportion in the size of the resource system (RS3) and user group (U1).

Although all communities have made efforts to address these problems, no community has been successful. There are three reasons for this failure. First, morels and ginseng are patchily distributed, seasonal nontimber forest products with very high market values (RU4), making them both difficult to monitor and rewarding targets for poachers (Poteete and Welch 2004). Second, the damage from poachers and trespassers appears to be small relative to the cost of imposing effective monitoring (although one poacher at Maple was caught with $\$ 20,000$ worth of ginseng). This is a trade-off; communities appear to view the financial and temporal costs of creating rules and monitoring trespassers as greater than the benefits they may bring. As a result, communities are forgoing monitoring and enforcement of violations (GS8). Although Twin Oaks and Box Elder have both made efforts to fence and walk the property to prevent ATVs from entering, these efforts have been too limited to be effective, particularly because the few residents of the community (U1) work, and thus spend most of the day outside of the community. Even Tulip Poplar, with a security committee of several volunteers organized through the community's formal governance system (GS5, GS6), continues to have problems with fishermen trespassing to fish in the community's lakes. Although it is conceivable that a full-time guard or guards could prevent trespassing, this would be very expensive even relative to the cost of stolen ginseng. Third, both rules (GS5) and norms (U6) in rural southern Indiana are not conducive to strict regulation of resource system boundaries (RS2). Rural residents are accustomed to walking, gathering nontimber forest products, and even driving ATVs across boundaries, and local laws make it difficult to enforce claims against trespassers. These norms and rules likely reflect a 19th-century institutional tradition in which forests were managed as open-access commons throughout much of North America (Freyfogle 2007). Although no community has been able to fully address these challenges, Box Elder and Tulip Poplar have been more successful than the others. In the case of Box Elder, this is due to their reliance on multiple strategies to deal with their neighbors, whereas Tulip Poplar has been more able to deal with trespassers due to their larger number of community members and more formal governance structure.

Two communities, Box Elder and Maple, have faced serious conflicts with neighbors (I3) resulting from perceived cultural differences between traditional rural communities and these so-called "hippie" communities. This has been a bigger problem for Box Elder. Box Elder's festivals attract crowds and are noisy. The community has suffered vandalism, has been accused by local newspapers of performing satanic rituals, and at one point was confused with a terrorist organization due to similarities in their names. Both communities have worked hard to reach across perceived cultural divides and improve relations with neighbors and local governmental authorities. Their efforts have resulted in new networks between the communities and their neighbors (GS3). Box Elder has also changed rules to decrease the noise impacts of their festivals on neighbors (GS5), underscoring how the community had to learn how to live with its neighbors. Maple's neighbor conflicts were less severe, and the community has been successful at addressing them through sustained cooperation with neighbors (GS3); however, Maple's severe problems with poaching persist.

It is important to note the nonlinearity in disturbances from neighbors and responses taken by the communities. For example, a lack of monitoring and sanctioning processes (GS8) were factors leading to the disturbance and response in the community of Twin Oaks. Given the inability to effectively monitor and sanction trespassing, the response represents a trade-off and opportunity cost to alternative responses; thus, it was maladaptive and contributed to the disturbance itself. 


\section{Membership transitions}

A fourth common disturbance type is related to transitions in membership as a result of the aging, dying, or departure of members. Unlike other disturbances we have discussed, these transitions are slow-moving processes, but this does not mean that their effects are small. Land tenure is a longterm commitment. Reduced membership can mean less available resources (financial and human) to cope with future disturbances, and if members continue to leave, the community will eventually disappear. Membership declines may also present opportunities for greater community cohesion if members who leave do not share the majority's values. Increases in membership can also be a source of disturbance. New members may lack knowledge about the institutional, organizational, and ecological aspects of the community or may not share all its norms and values. Thus, there may be a trade-off between bringing in new members, which can increase different forms of capital, and maintaining shared values and norms. This tradeoff, however, can be mediated by processes of acculturation about local rules and norms that also serve to select which individuals are to be invited into the community (see Gibson and Koontz 1998).

Two communities in our study, Maple and Oak, experienced substantial decreases in population from an original core group of about 40 people (see Table 2). Departures at Maple followed a major natural disaster (discussed below), and it appears that only the most committed stayed, strengthening the shared norms (U6) that contribute to Maple's ability to address many problems effectively. On the other hand, Maple's constitutional rules (GS7) do not allow for the incorporation of new members into the property-rights system (GS4), which has become a problem as members' children now wish to become members. Several members of Oak departed following the conflicts described previously in the section on tree cutting (Cutting of trees that violates rules or norms). Their departure was due to a lack of shared values (U6), conflicted leadership (U5), and constitutional rules (GS7) that were incapable of dealing with conflict. Those who left Oak were labeled "troublemakers" by remaining members; however, their departure, rather than leading to greater cohesion, led the remaining members to cease meeting, as they no longer had to deal with the problems created by troublemakers. Because the community no longer has a regular forum for making collective-choice rules (GS6), its ability to respond to future disturbances may be even more impaired than what it was during the past period of conflict.

Twin Oaks has also experienced a substantial decrease in population. The original community of four individuals never incorporated new members but remained stable for many years with little conflict. The small group size (U1) helped maintain shared norms and avoid conflicts; however, the recent death of one community member and the decision of two others to move to a warmer climate calls into doubt the long-term survival of the community. The ability of the community to respond in a way that would maintain the long-term viability of the community is hampered by the mental model (U7) the community has of itself. Community members see themselves as a group of friends and do not envision a community lasting beyond their own lifespans.

Although the other two communities, Box Elder and Tulip Poplar, have not experienced such large reductions in group size, they are not free from membership transitions, showing different degrees of membership increases and different responses to it. Although Box Elder has a stable group of core members, their strategy of drawing in less-involved members and visitors (in the hundreds) to participate in annual festivals has led to a different variant of the group size trade-off: festivals are a sort of investment (I5) to bring in resources but also cause environmental issues. Box Elder is trying to manage this problem by enforcing a ban on fuel wood collection by visitors during festivals and by designating specific areas for camping and prescribing the rotation of these areas every year so as to minimize the trampling of forest understory (GS5, GS8). Tulip Poplar, which has relatively open membership (S2), manages the issue of turnover by having a much more complicated system of formal rules than the other communities at both the collective-choice (GS6) and constitutional (GS7) levels.

\section{Natural disasters and "Acts of God"}

Whereas most of the disturbances described illustrate how users and governance systems interact with each other and affect the natural environment, natural disasters illustrate how resource systems can impact users and governance systems. Southern Indiana has a low frequency of major natural 
disasters, and modern societies are largely able to buffer themselves from major ecological disturbances (Kates 1971). There have been only two "natural" events that have had important impacts. The first, an "Act of God" in the insurance sense, was a building fire of unknown cause that occurred at Maple in 1980 (15 years before our first site visit). The second was a major flood that occurred at Tulip Poplar in the summer of 2008.

The fire at Maple destroyed what was then the main building of the community. For a group of young people whose communal finances were relatively precarious, this was a major disaster. As mentioned previously, many community members left the community after the fire. Rather than rebuilding the communal building, the remaining members of the community began building separate private dwellings. This process reflected the leadership (U5) of a small number of community members who had already begun building private dwellings. It also reflected the fact that users came from a socioeconomic background (U2) in which private dwellings, rather than communal ones, were the norm. This represented a major departure from the previous focus of the community, which was living together. A smaller community might not have been able to survive the loss of members, and a community with a weaker sense of collective action might have been crippled by the movement toward increased private land. Instead, Maple went through a transformation, remaining a community but becoming a community with substantially different goals.

The flood at Tulip Poplar was the result of an unusual series of very intense rainstorms that led to widespread flooding in southern Indiana. Tulip Poplar is located in a watershed that is vulnerable to flooding (U4). Damages to community-owned infrastructure, including roads and a dam spillway, amounted to five to six times the annual budget. In the immediate aftermath of the flood, the community's elected board and employees (U5) responded by rapidly mobilizing the community to address problems requiring immediate attention. The community has tried to take advantage of nested governance structures (GS3) by applying for state and federal disaster assistance. However, private homeowners associations such as Tulip Poplar are not generally eligible for such funding, which is restricted to governmental agencies or nonprofit organizations. At the time of our last site visit, in October 2008, the community was considering restructuring its governance arrangements so that in the future it might be better able to take advantage of intergovernmental linkages. Given that our last visit to the community was only 4 months after the flood, it is too early to evaluate long-term impacts.

\section{DISCUSSION}

Observing five similar forest communities responding to disturbances over time gives us insight into the processes leading to socialecological robustness. In particular, we find that adaptive responses to disturbances involving improvements to governance systems are associated with enhanced robustness, whereas failure to collectively learn from disturbances and appropriately adapt governance may result in declines in robustness. Anderies and Janssen (2007) argue that long-term robustness is a result of modest, shortterm cycles of failure and recovery. In our cases, we see that communities can learn from failures and change their institutions as a result of that learning. Ostrom (2005) argues that through collective experiences, culture, and communication, social learning takes place and groups retain or revise mental models that determine strategies for decision making. Alternatively, groups are able to overcome deficiencies in shared experiences, culture, or ineffective communication by establishing institutions that structure situations to enhance shared mental models, resulting in actions that lead to better rather than worse outcomes (North 2005). Either way, learning from experience, and using that learning to change institutions, is the core process that leads to enhanced robustness.

Three cases-Maple, Box Elder, and Tulip Poplar - are examples of communities that have increased their robustness through social learning, institutional changes that facilitate group decision making, and adaptation to disturbances. Maple and Box Elder both experienced major disturbances that threatened community viability (the fire at Maple and the conflict with the leader at Box Elder) that allowed them to restructure community governance in ways that were not only adaptive responses to the crisis at hand but also enhanced the ability of the community to respond to future disturbances, because the act of internally motivated adaptation is itself a collective experience that builds the scaffolding for future group decision making. Both Maple and Box Elder benefit from a relatively high level of cohesion (shared mental models) that we 
believe is the result of long and difficult collective experiences in the communities' initial years. The investment in developing a communicative group with a shared vision and supportive institutions provided these groups with robust foundations for decision making and, thus, adaptation. Tulip Poplar differs from Maple and Box Elder in being a much more heterogeneous community; however, it shares the characteristic of having a formal democratic governance system that facilitates shared understanding and group decision making and, thus, adaptation. At the time of our last visit, Tulip Poplar was in the process of revisiting this governance structure in response to governance challenges posed by a major disturbance (the flood). Tulip Poplar, like Maple and Box Elder, may emerge with a stronger governance system simply through the internal, collective, critical analysis process, building more scaffolding for future group decision making.

Two cases-Oak and Twin Oaks-have experienced disturbances that have not led to long-term robustness. Although they have survived thus far, their ability to respond to future disturbances is severely hampered by a lack of investment in internal problem solving and construction of institutional structures that support this process. In Oak, initial group heterogeneity, lack of shared mental models, and lack of effectively supportive institutions contributed to a long history of divisive conflict. Rather than respond to conflict-related disturbances by adaptively revising its governance structure, enhancing the community's long-term robustness, Oak abandoned its collective-choice rules and repeatedly turned to external authorities for conflict resolution. Underscoring the effect of an initial reliance on external actors to restructure the community in the face of major disturbance, Oak members collectively learned that investment in legal fees precluded investment in internally motivated adaptation for solving a second major social disturbance. Although we admit that there are cases in which external authorities, including courts, are warranted for conflict resolution, we observed that this repeated "solution" was maladaptive and represents Oak's lack of internal capacity for building robustness; court battles led to a loss of membership, and the current members no longer have a functioning collective-choice process that would enable them to communicate, share experiences, and thus internally respond to future disturbances. Twin Oaks, by contrast with the other four communities, has avoided major disturbances by remaining very small. But small size, as one member died and others have moved away, is now a weakness, threatening the group's viability, as does a shared vision that they are simply a group of friends, rather than a "formal community" with obligatory community roles and related institutions. Adaptation or its precursor, social learning, is unlikely to occur when individuals in a group do not participate with any induced need to perform or increase performance (Ostrom 2005); this appears to be particularly true with Twin Oaks, in which the disturbance faced is a more nebulous, pressing (as opposed to pulsing), or continuous disturbance event.

Looking at the individual variables from Ostrom's (2007, 2009) framework, we find that operational and collective-choice rules (GS5 and GS6), as well as norms/social capital (U6) and leadership (U5), were the factors most associated with adaptive responses. This is not surprising, as institutions are widely recognized as essential elements in social adaptation (Boyd and Richerson 2005, Ostrom 2005). Again, institutions structure situations to enhance shared mental models, resulting in actions that lead to better rather than worse outcomes (North 2005). Social learning and communication appear to play a key role in mediating institutional change, but it is not clear how these processes are modeled in the current version of Ostrom's framework. The importance of operational and collective-choice rules and monitoring and sanctioning processes associated with the upkeep of those rules has been emphasized in literature on the management of common-pool resources (Gibson et al. 2005, Basurto and Ostrom 2009, Coleman and Steed 2009). Not surprisingly, a lack of appropriate operational rules (GS5) or norms/social capital (U6) was associated with the causes of disturbance or maladaptive response, along with economic value (RU4) of nontimber forest products and small group size (U1).

\section{CONCLUSION}

Our analysis has illustrated how Ostrom's (2007) ontological framework can be applied to understanding the persistence of social-ecological systems subject to successive disturbances through anticipatory actions and responses on the part of the social actors in the system. The framework was originally proposed as a diagnostic framework for avoiding panaceas by enabling analysts to identify 
specific components of social-ecological systems. Basurto and Ostrom (2009) applied the framework by examining the emergence of self-organization and robustness. This paper takes a step forward by applying the framework to the over-time analysis of disturbances, responses, persistence, and robustness; this is a particularly innovative approach to comparative analysis of medium-N data sets.

We have shown that, although there are numerous variables that affect the robustness of communities to disturbances, a small number of variables are important in many of the cases. Our empirical results suggest that these variables-particularly operational and collective-choice rules, leadership and entrepreneurship, monitoring and sanctioning, economic values, number of users, and norms/social capital - should be at the core of future theoretical developments that aim to explain the variation in robustness across persistent communities. Overall, we conclude that successful communities exhibit a virtuous cycle in which group investment in careful crafting of institutions structures response to disturbance and builds scaffolding that facilitates social learning and collective decision making, leading to further institutional enhancement as need arises, and therefore, yields persistent communities, skillful at adapting and robust to future disturbance. Our findings are limited by the small number of cases examined here. However, our use of Ostrom's framework makes our cases potentially comparable to other cases coded using the same approach. A particularly promising approach would be to compare our results with cases studied over time by our IFRI colleagues in other countries, who have gathered data using identical protocols but in very different contexts.

Responses to this article can be read online at:

http://www.ecologyandsociety.org/voll5/iss4/art9/responses/

\section{Acknowledgments:}

We are grateful to the members of the five communities who are profiled in this paper for allowing us to study their communities. We owe the existence of this data set to the many IFRI scholars who have participated in data collection for this project over the last 15 years, as well as to the database support of Julie England and Robin
Humphrey. Funding for the IFRI research program has been provided by the Food and Agriculture Organization of the United Nations, Ford Foundation, MacArthur Foundation, and National Science Foundation. K. Daedlow's participation was funded through the project Adaptfish granted by the Gottfried-Wilhelm-Leibniz-Community, Germany. Funding for K. Boenning's participation was provided by the Leibniz Institute of Agricultural Development in Central and Eastern Europe (IAMO). F. Fleischman's participation was funded by an NSF Graduate Research Fellowship. We appreciate helpful comments and conceptual development from three anonymous reviewers; Amy Poteete, Gwen Arnold, and colleagues in the SocialEcological Systems Working Group at the Workshop in Political Theory and Policy Analysis, Indiana University, Bloomington; as well as editing from Patty Lezotte. A previous version of this paper was presented at the Workshop on the Workshop 4 conference, Indiana University, Bloomington, June 3-6, 2009.

\section{LITERATURE CITED}

Agrawal, A. 2001. Common property institutions and sustainable governance of resources. World Development 29(10):1649-1672.

Agrawal, A. 2007. Forests, governance, and sustainability: common property theory and its contributions. International Journal of the Commons 1(1):111-136.

Agrawal, A., A. Chhatre, and R. Hardin. 2008. Changing governance of the world's forests. Science 320(5882): 1460-1462.

Anderies, J. M., and M. A. Janssen. 2007. Robustness trade-offs in social-ecological systems. International Journal of the Commons 1(1):77-99.

Anderies, J. M., M. A. Janssen, and E. Ostrom. 2004. A framework to analyze the robustness of social-ecological systems from an institutional perspective. Ecology and Society 9(1):18.

Basurto, X., G. Kingsley, K. McQueen, M.Smith, and C. M. Weible. 2009. A systematic approach to institutional analysis: applying Crawford and Ostrom's grammar. Political Research Quarterly. 
[online] URL: http://prq.sagepub.com/content/early /2009/04/14/1065912909334430.

Basurto, X., and E. Ostrom. 2009. Beyond the tragedy of the commons. Economia delle fonti di energia e dell'ambiente 52(1):35-60.

Boyd, R., and P. J. Richerson. 2005. The origin and evolution of cultures. Oxford University Press, New York, New York, USA.

Brady, H. E., and D. Collier, editors. 2004. Rethinking social inquiry: diverse tools, shared standards. Rowman \& Littlefield, New York, New York, USA.

Brown, S. L., editor. 2002. Intentional community: an anthropological perspective. State University of New York Press, Albany, New York, USA.

Carlson, J. M., and J. Doyle. 2002. Complexity and robustness. Proceedings of the National Academy of Sciences 99(3):2538-2545.

Carpenter, S. R., B. H. Walker, J. M. Anderies, and N.Abel. 2001. From metaphor to measurement: resilience of what to what? Ecosystems 4 (8):765-781.

Chambers, R. 1994. The origins and practice of participatory rural appraisal. World Development 22 (7):953-969.

Cleaver, F. 2000. Moral ecological rationality, institutions and the management of common property resources. Development and Change 31 (2):361.

Coleman, E., and B. Steed. 2009. Monitoring and sanctioning in the commons: an application to forestry. Ecological Economics 68(7):2106-2113.

Crawford, S. E. S., and E. Ostrom. 1995. A grammar of institutions. American Political Science Review 89(3):582-600.

Fabricius, C., C. Folke, G. Cundill, and L. Schultz. 2007. Powerless spectators, coping actors, and adaptive co-managers: a synthesis of the role of communities in ecosystem management. Ecology and Society 12(1): 29. [online] URL: http://www.e cologyandsociety.org/vol12/iss1/art29/.
Fernandez-Gimenez, M. E., J. U. Hays, H. P. Huntington, R. Andrew, and W. Goodwin. 2008. Ambivalence toward formalizing customary resource management norms among Alaska native beluga whale hunters and Tohono O'odham livestock owners. Human Organization 67 (2):137-150.

Folke, C. 2006. Resilience: the emergence of a perspective for social-ecological systems analyses. Global Environmental Change 16(3):253-267.

Freyfogle, E. T. (2007). The enclosure of America (research paper no. 07-10). University of Illinois College of Law, Urbana-Champaign, Illinois, USA.

Gibson, C. C., and T. M. Koontz. 1998. When "community" is not enough: institutions and values in community-based forest management in southern Indiana. Human Ecology 26(4):621-647.

Gibson, C. C., J. T. Williams, and E. Ostrom. 2005. Local enforcement and better forests. World Development 33(2):273-284.

Harwell, M. A., W. P. Cropper, and H. Ragsdale. 1977. Nutrient recycling and stability: a reevaluation. Ecology 58:660-666.

Holling, C. S. 1973. Resilience and stability of ecological systems. Annual Review of Ecology and Systematics 4(1):1-23.

Janzen, D. E. 1981. The intentional communitynational community interface: an approach to the study of communal societies. Communal Societies 1:37-42.

Kanter, R. M. 1972. Commitment and community: communes and utopias in sociological perspective. Harvard University Press, Cambridge, Massachusetts, USA.

Kanter, R. M. 1973. Communes: creating and managing the collective life. Harper \& Row, New York, New York, USA.

Kates, R. W. 1971. Natural hazard in human ecological perspective: hypotheses and models. Economic Geography 47(3):438-451.

King, G., R. O. Keohane, and S. Verba. 1994. Designing social inquiry: scientific inference in qualitative research. Princeton University Press, 
Princeton, New Jersey, USA.

Kitts, J. A. 2000. Analyzing communal life spans: a dynamic structural approach. Communal Societies 20:13-25.

Kitts, J. A. 2009. Paradise lost: age-dependent mortality of American communes, 1609-1965. Social Forces 87(3):1193-1222.

Laffan, B. 1997. Communal organization and social transition: a case study from the counterculture of the sixties and seventies. Peter Lang, New York, New York, USA.

Larson, A., and J. C. Ribot. 2007. The poverty of forestry policy: double standards on an uneven playing field. Sustainability Science 2(2):189-204.

National Research Council. 2002. The drama of the commons. National Academies Press, Washington, D.C., USA.

North, D. C. 2005. Understanding the process of economic change. Princeton University Press, Princeton, New Jersey, USA.

Ostrom, E. 2005. Understanding institutional diversity. Princeton University Press, Princeton, New Jersey, USA.

Ostrom, E. 2007. A diagnostic approach for going beyond panaceas. Proceedings of the National Academy of Sciences 104(39):15181-15187.

Ostrom, E. 2009. A general framework for analyzing sustainability of social-ecological systems. Science 325(5939):419-422.

Ostrom, E., and M. B. Wertime. 2000. Appendix: international forestry resources and institutions research strategy. Pages 243-268 in C. C. Gibson, M. A. McKean, and E. Ostrom, editors. People and forests: communities, institutions, and governance. MIT Press, Cambridge, Massachusetts, USA.

Oved, Y. 1999. Communes in the twentieth century. Communal Societies 19:67-72.

Poteete, A. R., M. Janssen, and E. Ostrom. 2010. Working together: collective action, the commons, and multiple methods in practice. Princeton University Press, Princeton, New Jersey, USA.

Poteete, A., and E. Ostrom. 2008. Fifteen years of empirical research on collective action in natural resource management: struggling to build large-N databases based on qualitative research. World Development 36(1):176-195.

Poteete, A., and D. Welch. 2004. Institutional development in the face of complexity: developing rules for managing forest resources. Human Ecology 32(3):279-311.

Ragin, C. C. 2000. Fuzzy-set social science. The University of Chicago Press, Chicago, Illinois, USA.

Smit, B., and J. Wandel. 2006. Adaptation, adaptive capacity and vulnerability. Global Environmental Change 16(3):282-292.

Sunderlin, W. D., J. Hatcher, and M. Liddle. 2008. From exclusion to ownership? Challenges and opportunities in advancing forest tenure reform. Rights and Resources Group, Washington, D.C., USA.

Turner, B. L., II, R. E. Kasperson, P. A. Matson, J. J. McCarthy, R. W. Corell, L. Christensen, N. Eckley, J. X. Kasperson, A. Luers, M. L. Martello, C. Polsky, A. Pulsipher, and A. Schiller. 2003. A framework for vulnerability analysis in sustainability science. Proceedings of the National Academy of Sciences 100(14):8074-8079.

Walker, B., and D. Salt. 2006. Resilience thinking: sustaining ecosystems and people in a changing world. Island Press, Covelo, California, USA.

Wertime, M. B., E. Ostrom, C. Gibson, and F. Lehoucq. 2007. International forestry resources and institutions research program field manual (version 13). Center for the Study of Institutions, Population, and Environmental Change, Indiana University, Bloomington, Indiana, USA.

White, A., and A. Martin. 2002. Who owns the world's forests? Forest Trends, Washington, D.C., USA.

White, P. S., and S. T. A. Pickett. 1985. Natural disturbance and patch dynamics: an introduction. Pages 3-9 in S. T. A. Pickett and P. S. White, editors. The ecology of natural disturbance and patch dynamics. Academic Press, New York, New York, USA.

Wollenberg, E., L. Merino, A. Agrawal, and E. 
Ostrom. 2007. Fourteen years of monitoring community-managed forests: learning from IFRI's experience. International Forestry Review 9 (2):670-684.

Zablocki, B. 1980. Alienation and charisma: a study of contemporary American communes. Free Press, New York, New York, USA. 